\title{
PENGARUH COVID-19 TERHADAP OPERASIONAL DINING ROOM RESTORAN PENYEDIA HIDANGAN BARAT DI RUKO GOLDEN 8, GADING SERPONG, KECAMATAN KELAPA DUA, TANGERANG The Impact of Covid-19 on The Operation of Western Food Dining Restaurant in The Golden 8 Shophouse Gading Serpong, Kelapa Dua Sub-District, Tangerang
}

\author{
Riesta Carmelia ${ }^{1}$, Aurelie Carvina ${ }^{2}$, Sindi Agustina ${ }^{3}$, Diena Mutiara Lemy ${ }^{4}$ \\ 1,2,3,4 Program Studi Manajemen Perhotelan Fakultas Pariwisata, \\ Universitas Pelita Harapan \\ MH Thamrin Boulevard 1100, Klp. Dua, Kec. Klp. Dua, Tangerang, Banten \\ rc70026@student.uph.edu
}

Diterima: 05 Pebruari 2021. Disetujui: 24 Mei 2021. Dipublikasikan: 28 Juni 2021

\begin{abstract}
Abstrak
Penelitian ini bertujuan mengetahui dampak, upaya, serta kendala pihak pengelola restoran dalam menghadapi pandemi Covid-19 dan era kenormalan baru. Metode penelitian yang digunakan adalah penelitian kualitatif dengan analisis deskriptif eksploratif. Populasi dan sampel yang digunakan dalam penelitian ini adalah pengelola restoran yang berada di Ruko Golden 8 Gading Serpong, Kecamatan Kelapa Dua, Tangerang sebanyak tiga orang, setiap restoran mewakilkan satu orang untuk diwawancarai. Hasil penelitian ini mengungkapkan bahwa pandemi Covid-19 dan era normal baru memiliki dampak besar bagi keberlangsungan suatu restoran.
\end{abstract}

Kata Kunci: Covid-19, Ruko Golden 8, industri food and beverages, restoran penyedia hidangan barat.

\section{Abstract}

This study aims to find out the impacts, efforts, and constraints of restaurant managers in dealing with the Covid-19 pandemic and the new normal. The research method used is qualitative research with exploratory descriptive analysis. The population and samples used in this study were three people who manage the restaurant at Ruko Golden 8 Gading Serpong, Kelapa Dua District, Tangerang, each restaurant representing one person to be interviewed. The results of this study revealed that the Covid-19 pandemic and the new normal have a big impact on the sustainability of restaurant.

Keywords: Covid-19, the golden 8 shophouse, food and beverages industry, western food restaurant

(C) 2021 Direktorat Kajian Strategis 


\section{PENDAHULUAN}

Pada awal tahun 2020 terjadi wabah Corona Virus Disease 2019 atau Covid-19 (WHO, 2020) menyerang negara Tiongkok tepatnya di ibukota Wuhan provinsi Hubei lalu dengan cepat menyebar hampir ke seluruh belahan dunia sehingga berhasil mengganggu kegiatan aktivitas manusia hingga melumpuhkan hampir seluruh perekonomian dunia. Menurut Organization for Economic Cooperation and Development OECD (2020), pandemi Covid-19, peristiwa ini memiliki dampak yang sangat nyata dalam berbagai macam sektor, termasuk sektor pariwisata, yang memiliki peran penting bagi banyak orang, tempat, dan pebisnis.

Pariwisata memberi penghasilan devisa, mendorong pembangunan daerah, dan secara langsung mendukung pekerja dan pebisnis, serta membantu banyak masyarakat lokal. Oleh karena itu, pemerintah Indonesia menerapkan Pembatasan Sosial Berskala Besar (PSBB) di beberapa daerah di Indonesia dan pemberlakuan untuk tetap tinggal di dalam rumah. Berdasarkan laju pertumbuhan Produk Domestik Bruto Triwulanan tahun 2017 hingga 2020, telah terjadi penurunan yang drastis hingga ke angka 2,97\% (BPS, 2020). Ini berarti ekonomi Indonesia mencapai titik terendah dalam beberapa tahun belakangan. Semua industri dalam perekonomian terdampak kasus Covid19 ini, terutama industri akomodasi dan penyedia makanan minuman.

Badan Pusat Statistik (BPS) menyebutkan bahwa berdasarkan struktur dan pertumbuhan PDB menurut lapangan kerja secara nasional, seluruh sektor perekonomian di Indonesia benarbenar terdampak pandemi Covid-19. Sektor penyedia makan dan minum yang juga mengalami penurunan sebanyak $2,83 \%$ untuk tahun ini. Semasa PSBB total sektor penyedia makan dan minum tidak dapat beroperasional secara normal dan banyak restoran maupun gerai makanan dan minuman yang harus tutup karena PSBB (Prakoso, 2020). Oleh karena itu, sektor penyedia makan dan minum harus mengubah kembali sistem penjualan dan operasional jika ingin bertahan di situasi pandemi Covid-19 yang diprediksi baru berakhir di tahun 2021.

Contoh bisnis restoran dan penyedia makan dan minum yang mengubah sistem penjualan mereka adalah beberapa restoran yang harus tutup dan menyediakan frozen food sehingga dapat dihangatkan kembali di rumah, atau menyediakan jasa home service shabu dan $B B Q$ at home. Cara ini dilakukan untuk mencapai kepuasan pelanggan dan tetap bertahan di situasi pandemi Covid-19. Hal lain yang dilakukan oleh usaha di bidang makan dan minum adalah menjual makanan \& minuman sehat untuk menambah imunitas tubuh, menjual minuman dengan ukuran besar agar dapat dinikmati konsumen selama berhari-hari tanpa harus bepergian keluar rumah. Contohnya adalah gerai kopi Janji Jiwa yang menjual menu kopinya dalam bentuk botol literan.

Pada Juni 2020 pemerintah Indonesia menerapkan skenario tahapan normal baru. Toko, pusat perbelanjaan, perkantoran, dan restoran dapat kembali beroperasi dengan tetap mengikuti protokol kesehatan yang berlaku di Indonesia. Operasional restoran dalam masa normal baru telah menerapkan protokol kesehatan berupa mewajibkan pelanggan untuk menggunakan masker ketika memasuki restoran dan pengukuran suhu tubuh sebelum memasuki restoran. Cara ini digunakan untuk menghindari pelanggan yang berada dalam kondisi tidak sehat atau bergejala Covid-19. Restoran juga mengurangi 50\% kapasitas restoran agar jarak setiap pelanggan tetap terjaga sesuai protokol kesehatan yang berlaku. 
Setiap restoran menyediakan hand sanitizer untuk digunakan pelanggan yang akan makan di tempat. Ada pula restoran yang menyediakan menu elektronik untuk menghindari kontak langsung dengan buku menu dan karyawan restoran.

Charumilind, S., et al (2020) menjelaskan bahwa pandemi Covid-19 baru akan berakhir pada kuartal 3 atau kuartal 4 (Q3/Q4) tahun 2021. Hal ini perlu diperhatikan karena proses pembuatan vaksin cukup panjang dan harus melewati proses pembuatan berskala besar yang cukup lama.

Ruko Golden 8, Gading Serpong merupakan salah satu kawasan di Tangerang yang memiliki banyak usaha makanan dan minuman. Ruko Golden 8 sendiri adalah salah satu kompleks pertokoan paling berkembang yang dimiliki oleh PT Summarecon Agung Tbk pada kota mandiri Gading Serpong.

Pemilihan restoran hidangan Barat pada kawasan Ruko Golden 8 dikarenakan restoran tersebut cukup berkembang di wilayah Gading Serpong dan diminati oleh masyarakat. Oleh karena itu, peneliti memilih restoran penyedia hidangan Barat untuk diteliti. Besarnya peminat hidangan Barat hingga data ulasan pelanggan dari tiga situs ulasan restoran paling terkenal yaitu Google Reviews, Zomato, dan Pergikuliner.com menunjukan bahwa hidangan Barat memiliki keistimewaan bagi pelanggan, baik dari segi hidangan, pelayanan, maupun suasana restoran.

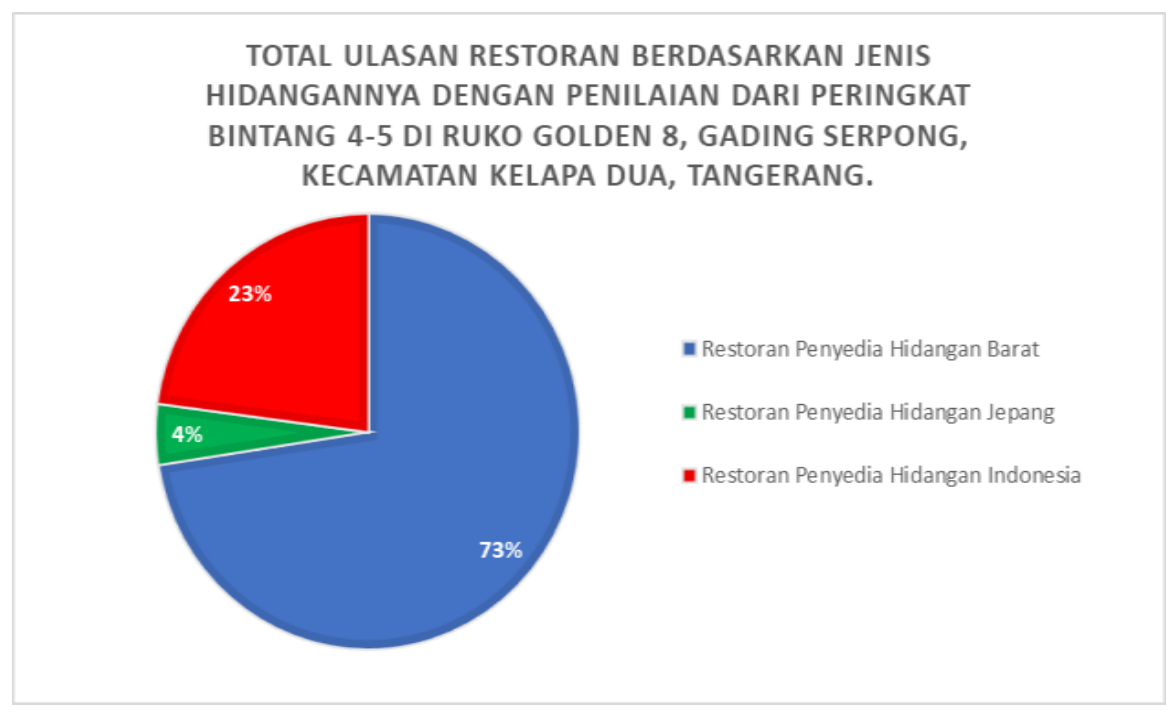

Gambar 1. Ulasan Restoran oleh Pelanggan pada Peringkat 4 -5 Bintang di Ruko Golden 8, Gading Serpong, Kecamatan Kelapa Dua, Tangerang

Sumber: Google Reviews, Zomato, dan Pergikuliner.com, diakses pada 13 Januari 2021 pukul 15.10 
Penelitian ini bertujuan mengetahui pengaruh, penyesuaian, kendala, dan upaya yang dilakukan oleh restoran hidangan Barat yang berada di Ruko Golden 8 Gading Serpong, Kecamatan Kelapa Dua dalam menghadapi era normal baru dan cara bertahan melewati masa pandemi Covid-19.

\section{Tinjauan Pustaka}

\section{Pariwisata}

Menurut UNWTO (2019), pariwisata adalah kegiatan sosial, budaya, dan ekonomi yang memerlukan pergerakan seseorang dari negara ke negara lain atau tempat-tempat di luar lingkungan tempat tinggal mereka yang biasa untuk tujuan pribadi atau bisnis/profesional.

Pergerakan wisatawan serta kegiatan jual beli jasa selama proses perpindahan maupun selama tinggal di destinasi tersebut merupakan suatu kegiatan ekonomi karena penyedia jasa menjual dan memfasilitasi kebutuhan wisatawan sedangkan wisatawan membeli produk jasa yang disediakan. Kegiatan penyediaan jasa ini merupakan salah satu sumber pendapatan bagi para penyedia jasa di destinasi wisata.

Salah satu kegiatan perdagangan jasa yang sangat dibutuhkan wisatawan yaitu industri jasa yang menyediakan food and beverage. Salah satu sarana yang menunjang kegiatan tersebut adalah tersedianya restoran atau rumah makan untuk memfasilitasi pelanggan dalam menikmati jasa layanan yang diberikan jasa tersebut.

\section{Restoran}

Walker (2017:4) menjelaskan bahwa restoran "play a significant role in our lifestyles, and dining out is a popular social activity. Everyone needs to eatso, enjoying good food and perhaps wine in the company of friends and in pleasant surroundings is one of life's pleasures. Eating out has become a way of life for families." Restoran merupakan bagian penting dalam kehidupan sehari-hari dan kegiatan sosial yang populer. Masyarakat pada zaman sekarang merupakan masyarakat yang terus berkembang sehingga manusia akan pergi ke restoran untuk bersosialisasi sambil menikmati makan dan minuman. Oleh karena itu, restoran merupakan lingkungan menyenangkan yang dapat dinikmati bersama teman ataupun keluarga.

Walker (2017:28) juga menjelaskan bahwa restoran memiliki beberapa tipe, yaitu sandwich shops, quick service, fast-casual, family restaurants, casual restaurants, fine dining, steakhouse, ethnic restaurants, theme restaurants, coffee shops, dan centralized home delivery restaurants.

Restoran penyedia hidangan Barat termasuk dalam jenis restoran sandwich stop, quick service, fast casual, family restaurants, casual restaurants, fine dining, steak house, ethnic restaurants, theme restaurants, coffee shop, serta centralized home delivery. Berdasarkan pengertian ini, dapat disimpulkan bahwa western restaurants dapat digolongkan ke dalam jenis-jenis restoran tersebut.

Menurut Amelia \& Garg (2016), western restaurant merupakan restoran yang menyediakan makanan Barat yang berasal dari benua Amerika dan Eropa. Secara eksterior dan interior, restoran Barat memiliki ciri khas pada desain bangunan dan restorannya, yang cenderung mengikuti tempat asalnya di negara Barat tersebut. Western restaurant sendiri biasanya selalu menyediakan minuman beralkohol, seperti wine dan cocktail untuk memperkaya rasa makanan Barat tersebut.

Menurut Zili (2017), hidangan Barat atau western food merupakan hidangan makanan yang berasal dari benua Eropa, Amerika, dan wilayah Oseania yang mendapatkan pengaruh dari masyarakat Eropa yang menetap di wilayah tersebut. Hidangan ini memiliki sifat cepat saji 
yang disebabkan oleh kultur kehidupan masyarakat di Eropa yang bergerak cepat dan dapat menyederhanakan proses pembuatan makanan dan minuman. Secara umum, makanan Barat mengacu pada makanan yang berasal dari benua Eropa dan negara Barat lainnya. Makanan Barat dalam arti lain juga disebut sebagai masakan kontinental. Dapat disimpulkan bahwa makanan Barat atau makanan kontinental memiliki banyak pengaruh dari benua Eropa, terutama Perancis, benua Amerika, serta wilayah Oseania.

Makanan Barat memiliki banyak sekali variasi sehingga memiliki ciri khas antara yang satu dengan yang lainnya. Dalam bentuk ukuran, makanan Barat dan makanan Asia memiliki perbedaan yang cukup signifikan. Makanan bergaya Barat cenderung memiliki porsi yang cukup besar dibandingkan makanan Asia. Dalam pengolahannya pun makanan Barat cenderung menggunakan berbagai herbs and spices yang berbeda dengan makanan Asia, seperti penggunaan oregano, thyme, dan basil serta bahan-bahan lainnya. Penggunaan wine juga sering digunakan dalam masakan Barat untuk memperkuat cita rasa makanan. Makanan Barat juga cenderung menggunakan kentang sebagai sumber karbohidrat utama, sedangkan dalam makanan Asia, penggunaan nasi lebih banyak digunakan sebagai sumber karbohidrat utama (Language \& Literature, 2017).

\section{Covid-19}

Virus adalah agen penularan terkecil. Virus pertama kali menginfeksi inang dengan cara menyerang mekanisme perlindungan tubuh inang lalu menyingkirkan daya tahan tubuh (imun), dan mematikan sel inang sehingga memicu peradangan pada daya tahan tubuh inang (Hayder dalam Hasan, 2020). Pada pertengahan Desember 2019 dan awal tahun 2020 terjadi kenaikan kasus penularan virus yang menginfeksi paru-paru. Hal ini disebabkan oleh virus baru yang belum diketahui jenisnya pada masa itu. Kasus ini pertama kali terdeteksi di Wuhan, provinsi Hubei, Tiongkok. Awalnya, kasus ini pertama kali terjadi di pasar seafood Huanan tetapi bertambah menjadi 240 kasus sehingga menjadi perhatian serius World Health Organization (WHO) karena penularannya yang sangat cepat.

SARS-CoV-2 hidup pada kulit manusia selama 10 menit dan pada benda mati selama 9 jam (WHO, 2020). Oleh karena itu, WHO menyarankan untuk melakukan jaga jarak ketika berinteraksi dengan manusia, menghindari kontak fisik, memakai masker, menghindari kerumunan, dan mencuci tangan maupun mandi setelah melakukan interaksi dengan manusia atau keluar rumah.

Gejala yang terjadi ketika seseorang terinfeksi Covid-19 adalah demam (> $38^{\circ} \mathrm{C}$ ) atau gejala pneumonia menengah, batuk dan pilek, diare, radang tenggorokan, dan kesulitan bernafas. Gejala ini terjadi selama 2-14 hari lamanya (Shrikrushna et al., 2020). Virus ini sangat rentan menginfeksi anak kecil, orang dewasa berumur di atas 59 tahun, dan ibu hamil (National Institutes of Health, 2020), orang dewasa yang telah berumur diatas 65 tahun dengan penyakit bawaan seperti diabetes dan hipertensi, resiko kematian pun lebih tinggi karena dapat menyebabkan shock dan gagal pernafasan (Yuki et al., 2020).

Menurut Kementerian Kesehatan Republik Indonesia (Kemenkes RI), protokol kesehatan adalah aturan dan ketentuan yang perlu diikuti oleh segala pihak agar dapat beraktivitas secara aman pada saat masa pandemi Covid-19 (Kemenkes RI, 2020).

Berdasarkan penjelasan di atas dapat diketahui bahwa protokol kesehatan Covid-19 merupakan suatu aturan tertulis yang bertujuan untuk mengontrol aktivitas tiap-tiap individu ataupun 
kelompok untuk melakukan kegiatan sehari-hari selama masa pandemi Covid19 ini.

Tujuan dibuatnya protokol kesehatan ini adalah membantu masyarakat dalam menghadapi adaptasi kebiasaan baru agar setiap individu- dapat tetap produktif dan aman dari Covid-19. Dengan adanya protokol kesehatan Covid-19 ini, diharapkan roda perekonomian di Indonesia tidak berhenti berputar. Ruang lingkup protokol kesehatan Covid-19 meliputi juga upaya pemerintah dalam mencegah dan mengendalikan Covid-19 di tempattempat serta fasilitas-fasilitas umum dengan memberikan perlindungan kesehatan kepada masing-masing individu dan perlindungan kesehatan masyarakat yang terdiri atas pengelola, penyelenggara, penanggung jawab serta fasilitas umum, dan juga masyarakat itu sendiri.

Menurut Kemenkes RI (2020), masyarakat di Indonesia memiliki peran yang sangat penting dalam memutus mata rantai penularan dan penyebaran Covid-19 di Indonesia. Hal ini dikarenakan masyarakat di Indonesia banyak bersosialisasi di tempat yang ramai dengan pergerakan manusia sehingga dikhawatirkan jika tidak adanya protokol kesehatan yang ditetapkan oleh Kemenkes RI, penyebaran Covid-19 di Indonesia semakin banyak, tidak terkendali, serta menimbulkan sumber-sumber penularan baru di tempat-tempat beraktivitas tersebut.

Pada masa pandemi Covid-19 ini, masyarakat harus beraktivitas untuk mendapatkan penghasilan. Pandemi Covid-19 membuat masyarakat harus menyesuaikan diri agar dapat beradaptasi dengan kebiasaan baru yang lebih bersih, lebih sehat, dan lebih disiplin sehingga dapat memutus mata rantai penyebaran Covid-19 ini.
Penularan Covid-19 terjadi melalui droplet yang sudah terinfeksi masuk ke tubuh manusia yang belum terinfeksi melalui mata, hidung, dan mulut. Prinsip utama perlindungan kesehatan pada individu berfokus untuk menghindari masuknya virus melalui ketiga pintu masuk tersebut dengan beberapa cara, seperti menggunakan Alat Pelindung Diri (APD) berupa masker yang menutupi mulut, hidung, sampai ke dagu. Penggunaan masker senantiasa dilakukan saat individu melakukan interaksi dengan individu lainnya. Masker yang disarankan adalah disposable mask maupun masker kain dengan 3 lapisan.

Hal lain yang dapat dilakukan adalah mencuci cuci tangan sesering mungkin dengan menggunakan sabun dan air mengalir atau menggunakan cairan antiseptik beralkohol atau hand sanitizer sebelum melakukan kontak langsung dengan mata, hidung, dan mulut. Selain itu, harus juga menjaga jaga jarak dengan individu lainnya sejauh minimal 1 (satu) meter saat berada di keramaian. Semua hal tersebut bertujuan untuk menghindari terkena droplet individu lain saat berbicara, bersin, ataupun batuk. Menjaga jarak juga bertujuan untuk meminimalisasi adanya kerumunan, keramaian, serta pergesekan individuindividu. Meningkatkan Perilaku Hidup Bersih dan Sehat (PHBS) dapat dilakukan dengan mengkonsumsi makanan dengan gizi seimbang, melakukan olahraga rutin, istirahat yang cukup, serta menghindari faktor-faktor penyebab penularan.

Restoran merupakan suatu usaha yang menyajikan hidangan berupa makanan dan minuman kepada masyarakat serta menyediakan tempat untuk menikmati makanan dan minuman tersebut dengan menentukan harga bagi makanan dan jasa layanannya. Restoran juga merupakan tempat masyarakat melakukan kegiatan sosial bertemu 
dengan individu-individu lainnya untuk berbagai alasan. Adanya kegiatan sosial akan menyebabkan adanya kerumunan. Pembatasan sosial harus diterapkan dengan cara menjaga jarak minimal satu meter di tiap tempat.

\section{METODE}

Rancangan penelitian ini menggunakan metode kualitatif dengan pendekatan deskriptif eksploratif. Tujuan penelitian ini adalah menganalisis, mencari, dan mengelola data langsung dari lapangan dengan melakukan observasi, dokumentasi, dan wawancara. Dalam penelitian ini peneliti berkomunikasi dan melakukan sebuah wawancara dengan memperhatikan pengumpulan data, waktu, dan sumbersumber yang diteliti. Metode penelitian ini memiliki tujuan menganalisis dan mendeskripsikan objek penelitian dalam hal sosial, sikap, serta pandangan secara perorangan atau kelompok.

Populasi adalah objek atau subjek yang memiliki karakteristik dan kualitas tertentu yang ditetapkan peneliti untuk dipelajari dan ditarik kesimpulannya (Sugiyono, 2017). Populasi penelitian ini adalah seluruh pengelola restoran hidangan Barat yang diwakili oleh para pengelola, sehingga ketiga orang ini akan menjadi subjek dalam penelitian ini.

Peneliti menggunakan teknik sampel jenuh atau sensus, dimana semua populasi akan dijadikan sampel dikarenakan jumlah anggota populasi sangat kecil dan sedikit atau kurang dari 30 orang (Sugiyono, 2015). Dalam penelitian ini, populasi hanya berjumlah tiga orang sehingga seluruh anggota populasi ini akan dijadikan sebagai sampel subjek penelitian.

Menurut Sugiyono (2015), data kualitatif adalah suatu data yang berupa kumpulan kata-kata, kalimat, skema, dan gambar; dan bukan merupakan suatu rangkaian angka sehingga tidak dapat disusun dan dimasukkan ke dalam suatu kategori atau struktur klasifikasi tertentu. Data kualitatif dapat dikumpulkan dengan berbagai metode, yakni observasi, wawancara, dokumentasi, dan studi pustaka. Menurut Sugiyono (2018:140) wawancara merupakan percakapan yang dilakukan oleh dua pihak, yaitu pewawancara yang memberikan pertanyaan dan pihak narasumber yang diwawancarai untuk memberikan jawaban.

Objek penelitian ini menggunakan wawancara yang terstruktur di mana pewawancara memberikan pertanyaan yang sudah disusun dan sesuai dengan daftar pertanyaan. Oleh karena itu, pewawancara akan mendapatkan jawaban yang dinginkan sesuai dengan subjek penelitian. Wawancara dilakukan dengan owner atau pemilik restoran atau kepala bagian dari restoran hidangan Barat.

Menurut Sugiyono (2018:240) dokumentasi adalah catatan sebuah peristiwa yang berbentuk foto, gambar, sketsa, dan lainnya. Dokumentasi merupakan pelengkap dari metode wawancara yang dilaksanakan. Dokumentasi juga merupakan pendukung dari penelitian, observasi, serta wawancara kepada ketiga restoran yang dipilih.

Menurut Nasution (dalam Sugiyono, 2018:226) observasi merupakan ilmu dasar dari pengetahuan. Ilmuwan dapat melakukan penelitian berdasarkan data, yaitu fakta dari dunia nyata yang diperoleh dari observasi dengan proses pengamatan dan ingatan. Dalam penelitian, menguji validitas data sangatlah penting. Penelitian kualitatif memiliki beberapa teknik untuk menguji apakah data penelitian tersebut dapat dikatakan sah atau benar.

Menurut Sekaran dan Bougie (2016:106), "triangulation is a technique 
that is also often associated with using mixed methods. The idea behind triangulation is the one can be more confident in a result of the use of different methods on sources leads to the same result.". Berdasarkan penjelasan itu, triangulasi merupakan teknik yang sering dikaitkan dengan penggunaan metode campuran di mana metode ini merupakan kumpulan data serta analisis dalam satu studi. Menggunakan metode triangulasi dapat membuat seseorang percaya diri dalam menggunakan hasil metode yang berbeda sehingga memiliki hasil yang sama.

Pengertian lainnya menurut Sugiyono (2017:273) adalah triangulasi merupakan metode untuk mendapatkan sumber yang berbeda-beda dengan memiliki teknik yang sama, yaitu wawancara terstruktur, observasi, serta dokumentasi.

Dalam penelitian ini, peneliti menggunakan metode triangulasi untuk memeriksa keabsahan data. Sekaran \& Bougie (2016) menjelaskan bahwa terdapat empat teknik triangulasi, yaitu (1) triangulasi metodologi, triangulasi data, (3) triangulasi penelitian, dan (4) triangulasi teori.

Berdasarkan teknik triangulasi di atas, peneliti menggunakan teknik triangulasi metodologi, yakni teknik yang merujuk pada penggunaan beberapa teknik dalam mengumpulkan dan menganalisis data. Untuk mendapatkan keabsahan data, peneliti tidak hanya melakukan wawancara tetapi juga melakukan observasi terlebih dahulu dan melakukan dokumentasi sehingga data yang dibutuhkan bisa didapatkan.

\section{HASIL DAN PEMBAHASAN}

Penelitian ini berfokus pada pengaruh pandemi Covid-19 terhadap dunia industri kuliner, terutama restoran yang menyediakan hidangan Barat yang terletak di Ruko Golden 8 Gading
Serpong, Kecamatan Kelapa Dua, Tangerang, Penelitian ini bertujuan melihat perubahan yang dilakukan oleh restoran yang menyediakan hidangan Barat tersebut sebelum masa pandemi, semasa pandemi, dan selama era normal baru. Ada beberapa restoran yang memiliki hidangan Barat, di antaranya yaitu: B'Steak Grill \& Pancake, Amyrea Art \& Kitchen, Common Strangers, Turning Point, Porto Bistreau, dan Crematology.

Dari keenam nama restoran yang sudah di sebutkan di atas, hanya tiga restoran penyedia hidangan Barat yang memberi konfirmasi untuk dapat diwawancarai, yaitu Common Strangers, Amyrea Art \& Kitchen, dan B'steak Grill \& Pancake. Turning Point dan Crematology tidak memberi konfirmasi sedangkan Porto Bistreau tidak beroperasi selama pandemi Covid-19 sehingga tidak dapat dilakukan wawancara dan pengambilan data.

Narasumber penelitian ini adalah Bapak Alexander, pemilik sekaligus pengelola Café Common Strangers; Bapak Kenzo Therin, pemilik Amyrea Kitchen \& Art; dan Bapak Mahpudin, leader di B'Steak Grill \& Pancake. Setelah melakukan analisis data yang diperoleh dari wawancara, peneliti mendapatkan hasil sebagai berikut.

Pada bagian pertama peneliti menanyakan pengaruh Covid-19 terhadap restoran penyedia hidangan Barat. Hasilnya adalah semasa pandemi Covid-19, pihak pengelola restoran sudah berusaha melakukan yang terbaik bagi pelanggan namun tetap mengalami kesulitan dengan adanya peraturan pemerintah yang mengurangi jam operasional restoran. Pengurangan jam operasional membuat, restoran mengalami kendala baru, yaitu pihak pengelola restoran harus mampu mencapai target penghasilan normal meskipun mengalami pengurangan jam operasional restoran. Pengurangan jam 
operasional restoran ini juga merugikan pihak restoran maupun karyawan kendati demikian restoran tetap mengikuti peraturan pemerintah agar dapat terus beroperasi di masa pandemi Covid-19. Restoran juga mengalami penurunan pendapatan semasa pandemi Covid-19 ini namun pengeluaran untuk operasional restoran mengalami kenaikan. Hal ini dikarenakan pihak pengelola harus mengalokasikan pengeluaran tambahan untuk membeli sabun, disinfektan, dan hand sanitizer dalam jumlah yang cukup banyak. Pengurangan jam operasional restoran ini juga mengakibatkan menurunnya jumlah pengunjung restoran. Imbas dari kenaikan biaya pengeluaran dan operasional adalah pihak restoran harus melakukan pengurangan karyawan pada pertengahan tahun 2020 .

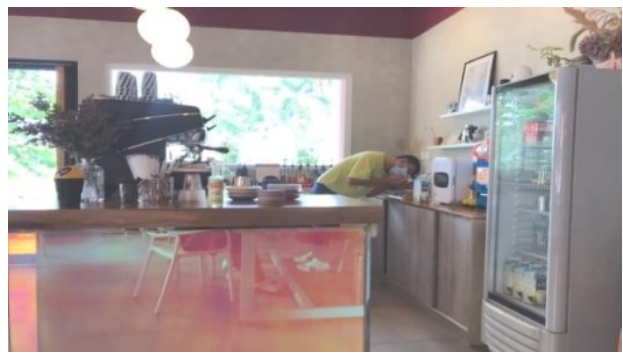

Gambar 2. Karyawan Café Common Strangers dengan Protokol Kesehatan

Beberapa penyesuaian dilakukan oleh pihak restoran dalam memasuki era adaptasi normal baru, yaitu mematuhi protokol kesehatan yang sudah ditetapkan oleh pemerintah. Pihak restoran juga melakukan general cleaning secara berkala setiap hari dengan tujuan membantu pemerintah mencegah penyebaran Covid-19 dan menciptakan kenyamanan dan kebersihan tambahan bagi pelanggan dan karyawan. Dengan mengikuti protokol kesehatan yang telah diberikan pemerintah, restoran berharap dapat bertahan dalam situasi pandemi dan pelanggan merasa nyaman dan aman selama makan di tempat.

Pihak restoran pun melakukan upaya lain untuk memutus mata rantai penyebaran Covid-19 dengan cara menerapkan social distancing pada pelanggan di restoran. Pihak restoran tidak mengizinkan karyawan restoran yang sedang tidak sehat untuk bekerja. Hal ini dilakukan untuk mencegah penyebaran Covid-19.

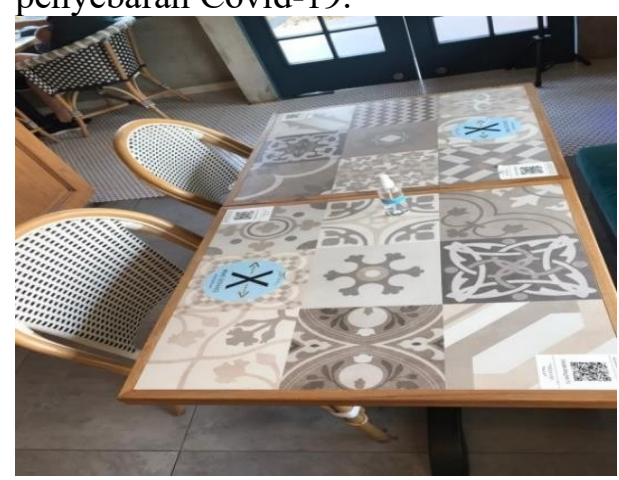

Gambar 3. Protokol Kesehatan pada Amyrea Art \& Kitchen

Pengelola restoran memiliki kendala dalam menghadapi era normal baru, seperti sulitnya mengikuti kebijakan pemerintah yang terus berubah. Hal ini mengakibatkan pihak restoran mengalami beberapa kerugian. Contohnya adalah jam operasional restoran dikurangi sehingga pihak manajemen restoran harus kembali mengatur pembagian waktu kerja yang seharusnya tiga shift menjadi satu shift. Pemberlakuan Pembatasan Sosial Berskala Besar (PSBB) menjadi kendala sendiri bagi pihak restoran karena pemerintah secara tiba-tiba membuat peraturan tersebut sehingga restoran sulit melakukan adaptasi dan penyesuaian. Pengurangan jam operasional restoran juga mengakibatkan pihak restoran akhirnya harus merumahkan beberapa karyawan untuk mengurangi beban biaya yang harus dibayarkan. 


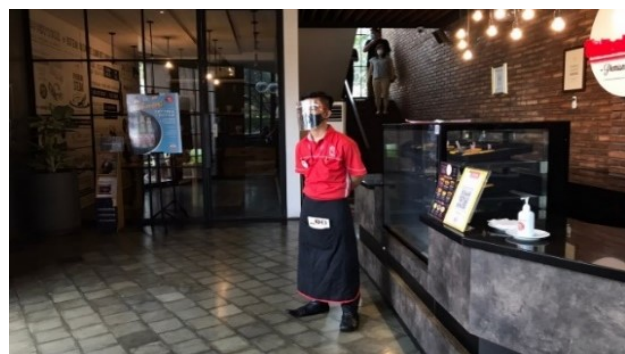

Gambar 4. Grooming Karyawan B'Steak Grill \& Pancake pada Era Normal Baru

Pihak restoran melakukan berbagai upaya untuk dapat bertahan di kala pandemi Covid-19, yaitu senantiasa menjaga food hygiene, excellent service, dan quality production. Ketiga hal ini menjadi pegangan bagi restoran untuk menarik pelanggan agar merasa nyaman dan aman selama berada di restoran. Pihak restoran juga melakukan suatu upaya agar tetap bisa mendapat penghasilan serta mengimbangi seluruh biaya operasional.

Upaya lain yang dilakukan oleh pihak pengelola restoran adalah melakukan penghematan listrik serta mengurangi tenaga kerja untuk menyeimbangkan jumlah pengeluaran dan pemasukan restoran. Selain itu, pihak restoran memberi promo-promo yang menarik bagi pelanggan agar tetap mau mengunjungi restoran tersebut. Pihak restoran juga memberi beberapa menu baru yang diharapkan dapat menarik kembali minat beli pelanggan. Hal lainnya adalah menjalankan usaha delivery, frozen food, dan bekerja sama dengan go-food maupun grab food. Restoran pun selalu menjaga kebersihan demi kenyamanan pelanggan.

\section{SIMPULAN}

Penelitian ini dilakukan dengan tujuan melihat pengaruh Covid-19 terhadap restoran hidangan Barat di Ruko Golden 8, Gading Serpong, Kecamatan Kelapa Dua, Tangerang. Berdasarkan hasil wawancara yang sudah dilakukan dan uraian yang dijelaskan pada pembahasan di atas, dapat disimpulkan bahwa Covid-19 sangat berpengaruh terhadap operasional restoran. Terjadi banyak perbedaan pada saat sebelum pandemi terjadi, setelah pandemi, dan pada saat era normal baru. Pengaruh pandemi Covid-19 telah membuat restoran harus mengalami pengurangan jam operasional restoran, penurunan pendapatan, dan pembengkakan biaya pengeluaran. Selain itu, beberapa penyesuaian juga dilakukan oleh restoran, yakni mengikuti protokol kesehatan yang telah dicanangkan pemerintah dan melakukan general cleaning setiap hari, sebelum dan sesudah jam operasional restoran. Di balik penyesuaian yang dilakukan restoran, terdapat kendala-kendala yang dihadapi, yaitu manajemen restoran harus kembali mengatur pembagian waktu kerja bagi karyawan sebagai imbas dari pengurangan jam operasional restoran, terdapat pelanggan yang masih sulit mengikuti protokol kesehatan walaupun sudah diingatkan, dan sulitnya pihak restoran mengikuti peraturan Pembatasan Sosial Berskala Besar (PSBB) karena sering kali terkesan mendadak ditetapkan oleh pemerintah.

Meski terdapat kendala, pihak restoran memiliki upaya untuk bertahan di kala pandemi, yaitu menjaga food hygiene, excellent service, dan quality production sehingga restoran dapat memperoleh brand trust dari pelanggan. Hal lain yang dilakukan oleh restoran adalah melakukan penghematan listrik, megurangi tenaga kerja, memberikan promo-promo yang menarik, dan menjalankan usaha dengan food delivery.

\section{DAFTAR PUSTAKA}

Amelia, M., \& Garg, A. (2016). The first impression in a fine-dining restaurant. A study of C Restaurant 
in Tampere, Finland. European Journal of Tourism, Hospitality and Recreation.

https://doi.org/10.1515/ejthr-20160012.

Badan Pusat Statistik. (2020). Pertumbuhan Ekonomi Indonesia Triwulan IV-2019. www.bps.go.id

BPS. (2020). Pertumbuhan Ekonomi Indonesia (Produk Domestik Bruto), Perkembangan Tenaga Kerja Indonesia Februari 2020; Catatan Peristiwa Triwulan I-2020. Berita Resmi Statistik, 5 Mei

Charumilind, S., Craven, M., Lamb, J., Sabow, A., \& Wilson, M. (2020). When Will the Covid-19 Pandemic End. McKinsey \& Company Healthcare Systems \& Services. https://www.mckinsey.com/industr ies/healthcare-systems-andservices/our-insights/when-willthe-Covid-19-pandemic-end

Covid-19 Pandemic in Indonesia (2020). Wikipedia Encyclopedia https://en.wikipedia.org/wiki/ COVID-

19_pandemic_in_Indonesia

Hasan, T. H. (2020). Extended Spectrum Beta Lactamase E. Coli Isolated From Uti Patients In Najaf Province, Iraq. International Journal of Pharmaceutical Research. https://doi.org/10.31838/ijpr/2020. 12.04.049

Lai, C. C., Shih, T. P., Ko, W. C., Tang, H. J., \& Hsueh, P. R. (2020). Severe Acute Respiratory Syndrome Coronavirus 2 (SARS-CoV-2) and coronavirus Disease-2019 (Covid19): The Epidemic And The Challenges. International Journal of Antimicrobial Agents. https://doi.org/10.1016/j.ijantimica g.2020.105924

Language, C., \& Literature. (2017). The Differences of Chinese and Western Food Cultures. Literature \& Culture.
Kementrian Kesehatan RI. (2020). Keputusan Menteri Kesehatan RI Nomor

Hk.01.07/Menkes/382/2020.

Peraturan Menteri Kesehatan Republik Indonesia.

Prakoso, Fajar A. (2020). Dampak Coronavirus Disease (Covid-19) Terhadap Industri Food \& Beverages. Manajemen Bisnis.

Walker, J. R. (2017). Restaurant Concepts, Management and Operations Eight Edition. In Wiley

Sekaran, U., dan Bougie, R. (2016). Research Method for Business Textbook: A Skill Building Approach. John Wiley \& Sons Ltd

Sugiyono. (2017). Metode Penelitian Bisnis (Pendekatan Kuantitatif, Kualitatif, Kombinasi dan R\&D). Metodelogi Penelitian.

------. (2018). Metode Penelitian Kombinasi (Mixed Methods). Bandung: Alfabet.

------. (2018). Metode Penelitian Kuantitatif, Kualitatif, dan R\&D. Bandung: Alfabet

UNWTO. (2014). Glossary of Tourism Terms. New York: UNWTO.

World Health Organization. (2020). Naming The Coronavirus Disease (Covid-19) and The Virus that Causes it. New York: WHO.

Yuki, K., Fujiogi, M., \& Koutsogiannaki, S. (2020). COVID-19 Pathophysiology: A review. In Clinical Immunology. https://doi.org/10.1016/j.clim.2020. 108427.

Zili, X. (2017). The Differences of Chinese and Western Food Cultures. Journal Chinese Language, Literature \& Culture, 2(1), 6-9 